\title{
Strategi Memanfaatkan Peluang Pasar Produk Pertanian Dalam Perdagangan Internasional
}

\author{
Esa Diya Wahyuni \\ Universitas Ekasakti Padang, Indonesia \\ Email: esa_diya@yahoo.co.id
}

\begin{abstract}
ABSTRAK
Ada begitu banyak peluang pasar produk pertanian ke luar negeri yang bisa dikuasai oleh Indonesia. Sehingga bila Indonesia dapat mengambil peran dalam perdagangan internasional maka tentunya akan meningkatkan pendapatan/devisa negara. Tulisan ini bertujuan untuk 1) Mengetahui peluang pasar produk pertanian dalam perdagangan internasional dan 2) Mengetahui bagaimana strategi memanfaatkan peluang pasar produk pertanian dalam perdagangan Internasional. Penulisan artikel ini dilakukan dengan metode deskriptif kualitatif terhadap hasil analisis dari berbagai referensi sesuai dengan tujuan penulisan. Kesimpulan pada tulisan ini adalah 1) Peluang pasar ekspor sangat terbuka lebar bagi para petani di Indonesia, sehingga diharapkan produk komoditas yang dihasilkan para petani dalam negeri bisa bersaing dengan produk lainnya dari negara tetangga, 2) Produk-produk pertanian yang termasuk ke dalam produk perkebunan yang memiliki peluang ekspor yang cukup baik dalam perdagangan internasional diantaranya adalah teh, karet, kopi, sawit, rotan, cengkeh, kapulaga, kulit manis, pala, gambir, tebu (gula), dan coklat, 3) Produk-produk pertanian yang termasuk ke dalam produk hortikultura yang memiliki peluang ekspor adalah sayuran seperti Cabbage (sayur pangsit) dan bayam, buah-buahan seperti manggis, pepaya, pisang, dan salak, serta tanaman hias seperti Palem Jari (Raphis Excelsa), 4) Produk-produk pertanian yang termasuk kedalam peternakan yang memiliki peluang ekspor yaitu produk olahan hasil peternakan yaitu rendang diekspor ke negara-negara Amerika dan negara-negara lainnya di seluruh dunia, 5) Strategi untuk memanfaatkan peluang pasar produk pertanian dimulai dari pemberdayaan petani sehingga petani dapat menghasilkan produk yang baik. Selanjutnya, produk pertanian harus mempunyai standar mutu yang baik sesuai dengan yang disyaratkan dalam perdagangan internasional. Seterusnya, meningkatkan dan mengefektifkan lobi perdagangan oleh para eksportir di Indonesia sehingga dapat menjual produk pertanian pada importer di luar negeri dengan harga yang lebih tiggi. Terakhir, diperlukan nilai tambah lebih untuk meningkatkan nilai jual produk pertanian maka perlu didorong pengembangan industri pengolahan hasil pertanian.
\end{abstract}

Kata kunci: Strategi, Peluang Pasar Produk Pertanian, Perdagangan Internasional.

\section{Pendahuluan}

Produk pertanian memiliki peluang yang cukup menjanjikan di kancah perdagangan internasional. Dalam perdagangan internasional produk pertanian dari Indonesia mengambil peran untuk dikonsumsi oleh masyarakat luar negeri. Adapun produk-produk pertanian dari Indonesia yang memiliki nilai komersial yang tinggi diantaranya produk perkebunan, hortikultura, peternakan, dan perikanan. Hasil perkebunan yang diekspor biasanya berupa produk setengah jadi dan produk jadi. Selanjutnya, produk hortikultura yang diekspor biasanya 
Jurnal EKOBISTEK, Vol.10, No. 1. Januari 2021, Hal 57-64, ISSN : 2301-5268 | E-ISSN : 2527-9483 Copyright@2021 6y LPPSM VPI YPTK Padang

produk yang masih berupa produk segar. Untuk produk peternakan yang biasanya diekspor adalah produk setengah jadi.

Irawan, Bambang dan Ening Ariningsih (2020) menyatakan bahwa defisit perdagangan terjadi dalam perdagangan sayuran dan buah pada negara-negara Eropa dan USA baik dalam nilai perdagangan maupun dalam kuantitas perdagangan. Rasio nilai impor terhadap nilai ekspor paling tinggi di negara-negara Eropa yaitu sekitar 1,38 - 1,66 selama tahun 1980-2011 yang artinya negara-negara tersebut mengalami defisit perdagangan sayuran dan buah sekitar 38\% $66 \%$. Defisit perdagangan sayuran dan buah juga terjadi di negara USA sekitar 24\% - 34\% pada periode 1990-2010. Nilai rasio tersebut pada negara Asia dan negara berkembang lainnya umumnya lebih kecil dari satu yang artinya negara-negara Asia dan negara berkembang lainnya umumnya memiliki surplus dalam perdagangan sayuran dan buah. Berdasarkan hal tersebut maka dapat dikatakan bahwa pada perdagangan sayuran dan buah negara-negara Eropa dan USA cenderung berperan sebagai importir sedangkan negara-negara Asia dan negara berkembang lainnya berperan sebagai eksportir. Dengan kata lain arus perdagangan sayuran dan buah cenderung bergerak dari negara-negara Asia dan negara berkembang lainnya serta menuju ke negara-negara maju.

Indonesia memiliki kekayaan alam daratan dan lautan yang dapat diperbaharui dengan dukungan sumberdaya manusia, tekhnologi, dan agroklimat. Indonesia memiliki jumlah penduduk yang cukup banyak kurang lebih 220 juta jiwa dengan jumlah penduduk yang banyak ini kita bisa mengembangkan pertanian lebih luas. Selanjtnya, Indonesia juga telah mengadopsi tekhnologi dari luar serta melakukan penelitian tentang tekhnologi hasil pertanian, hal ini bisa membantu petani dan pengusaha untuk mengembangkan tekhnologi. Selanjutnya secara agroklimat Indonesia memiliki iklim yang mendukung untuk pertanian karena terdiri dari dua musim yaitu musim panas dan hujan sepanjang tahun, dengan ini maka petani dapat berproduksi sepanjang tahun.

Dengan kekuatan yang dimiliki tersebut, Indonesia sudah seharusnya mampu menangkap peluang pasar di dalam negeri khususnya dan di luar negeri pada umumnya. Bila Indonesia banyak melakukan ekspor maka akan mendatangkan devisa untuk negara sehingga negara menjadi makmur. Kemakmuran yang ingin diperoleh tersebut harusnya dilakukan dengan upaya yang sungguh-sungguh oleh semua pihak. Berdasarkan hal tersebut penulis tertarik untuk menulis artikel yang berjudul "Strategi Memanfaatkan Peluang Pasar Produk Pertanian dalam Perdagangan Internasional”.

Penulisan artikel ini bertujuan untuk mengetahui peluang pasar produk pertanian dalam perdagangan internasional dan untuk mengetahui bagaimana strategi memanfaatkan peluang pasar produk pertanian dalam perdagangan Internasional. Penulisan artikel ini bermanfaat bagi petani untuk mengetahui strategi memanfaatkan peluang pasar produk pertanian dalam 
Jurnal EKOBISTEK, Vol.10, No. 1. Januari 2021, Hal 57-64, ISSN : 2301-5268 | E-ISSN : 2527-9483 Copyright@2021 by LPPM UPI YPTK Padang

perdagangan internasional. Selanjutnya, dapat menjadi inspirasi bagi pembaca untuk meneliti lebih lanjut tentang peluang pasar pada produk pertanian dalam perdagangan internasional.

\section{Metodologi Penelitian}

Dalam penulisan ini, pembahasan dilakukan dengan metode deskriptif kualitatif terhadap hasil analisis dari berbagai referensi sesuai dengan tujuan penulisan. Berbagai penelitian terkait dengan peluang pasar produk pertanian dalam perdagangan internasional dan strategi memanfaatkan peluang pasar produk pertanian dalam perdagangan Internasional. Tulisan ini juga memuat review dari berbagai hasil penelitian yang terkait, sesuai tujuan penulisan serta untuk menambah wawasan pembahasan dan mendasari pengambilan kesimpulan, saran dalam strategi memanfaatkan peluang pasar produk pertanian dalam perdagangan internasional.

\section{Hasil Dan Pembahasan}

a. Mengetahui peluang pasar produk pertanian dalam perdagangan internasional.

Pada dasarnya hasil pertanian beserta produk-produk turunannya memiliki potensi pasar yang cukup bagus. Bahkan tidak hanya di pasar lokal dan nasional saja kebutuhan produk pertanian banyak diminati para pelanggan, tetapi sekarang ini peluang pasar ekspor sangat terbuka lebar bagi para petani di Indonesia, sehingga diharapkan produk komoditas yang dihasilkan para petani dalam negeri bisa bersaing dengan produk lainnya dari negara tetangga (Anonimus, 2011)

Produk-produk pertanian yang termasuk ke dalam produk perkebunan yang memiliki peluang ekspor yang cukup baik dalam perdagangan internasional diantaranya adalah teh, karet, kopi, sawit, rotan, cengkeh, kapulaga, kulit manis, pala, gambir, tebu (gula), dan coklat. Suprihartini mengatakan bahwa untuk teh dipasarkan ke Srilangka, Kenya, Cina, dan India. Namun, ada beberapa negara-negara tujuan ekspor teh Indonesia seperti Pakistan, Inggris, Belanda, Jerman, Irlandia, Rusia, Amerika Serikat, Singapura, Malaysia, Siria, Taiwan, Mesir, Maroko, dan Austria yang diambil alih oleh negara produsen teh lainnya (Suprihartini, 2005). Seterusnya, ditambahkan oleh Hutabarat, sasaran pasar komoditas kopi Indonesia adalah Jepang, Amerika Serikat, Jerman, Italia, dan Belanda (Hutabarat, 2006).

Produk-produk pertanian yang termasuk ke dalam produk hortikultura yang memiliki peluang ekspor adalah sayuran seperti Cabbage (sayur pangsit) dan bayam. Buah-buahan seperti manggis, pepaya, pisang, dan salak. Tanaman hias seperti Palem Jari (Raphis Excelsa). Sayuran seperti sayur pangsit dipasarkan ke Singapura. Sedangkan produk buah-buahan di pasarkan ke negara-negara Amerika. Seterusnya, untuk tanaman hias dipasarkan ke Belanda dan Arab. 
Kustiari, Reni, Helena J. Purba, dan Hermanto (2012), menyatakan bahwa volume ekspor manggis Indonesia meningkat dari waktu ke waktu, namun pangsa pasar dan daya saing ekspornya cenderung turun. Oleh karena itu, diperlukan upaya untuk meningkatkan kualitas dan mencari negara yang permintaan impornya besar dengan laju pertumbuhan yang cepat. Selain itu, perlu dijajagi upaya diversifikasi produk (hasil olahan manggis) untuk meningkatkan harga per unit ekspor dan meningkatkan nilai tambah produsen.

Produk-produk pertanian yang termasuk kedalam peternakan yang memiliki peluang ekspor yaitu produk olahan hasil peternakan yaitu rendang diekspor ke negara-negara Amerika dan negara-negara lainnya di seluruh dunia. Menurut hasil penelitian, pada salah satu media masa di dunia, rendang ditetapkan sebagai makanan terlezat di dunia.

Berdasarkan hal di atas, begitu banyak peluang pasar luar negeri yang bisa dikuasai oleh Indonesia. Indonesia harus tetap mempertahankan untuk mengekspor produk-produk pertanian ke pasar luar negeri tersebut. Sehingga bila Indonesia dapat mengambil peran dalam perdagangan internasional maka tentunya akan meningkatkan pendapatan/devisa negara.

\section{b. Mengetahui bagaimana strategi memanfaatkan peluang pasar produk pertanian dalam perdagangan Internasional.}

Mengingat semakin ketat persaingan perdagangan internasional maka dilakukan upaya (kiat) yang lebih nyata dan terkoordinasi di dalam mendorong produk pertanian untuk mampu menembus pasar internasional. Beberapa hal mendasar yang harus dilakukan antara lain adalah: (1) Edukasi terhadap petani tentang persyaratan kualitas produk pertanian yang lebih tinggi, (2) Pelatihan tekhnis penjamin mutu budidaya, (3) Membuat kebijakan pembangunan pertanian yang lebih kondusif bagi petani untuk dapat bersaing di pasar internasional, misalnya dengan memberikan insentif pajak atau subsidi harga, (4) Meningkatkan dan mengefektifkan lobi perdagangan internasional, (5) Memperluas pasar internasional dengan produk-produk pertanian yang khas Indonesia sehingga mempunyai keuntungan komparatif.

Lobi perdagagan dapat dilakukan dengan lebih mengefektifkan peranan atase perdagangan danatase pertanian di luar negeri atau dengan mendirikan kantor khusus yang menangani perdagangan produk pertanian di negara yang potensial sebagai pengimpor produk Indonesia. Selain itu, juga perlu difikirkan kebijakan membuka pintu impor produk pertanian ke Indonesia secara tak terkendali yang justru merugikan posisi petani di dalam negeri. Membanjirnya 
Jurnal EKOBISTEK, Vol.10, No. 1. Januari 2021, Hal 57-64, ISSN : 2301-5268 | E-ISSN : 2527-9483 Copyright@20216y LPPM VPI YPTK Padang

produk pertanian impor, yang bersaing secara langsung dengan produk dalam negeri dan dengan harga yang murah dapat menumbuhkan perasaan frustasi petani untuk melakukan usaha tani.

Perluasan pasar internasional dengan komoditas pertanian yang khas Indonesia perlu dipikirkan sehingga komoditas pertanian Indonesia tidak harus bersaing head to head dengan produk sejenis di luar negeri. Upaya ini tentunya akan terkait dengan kebijakan pertanian yang lebih komprehensif, misalnya dengan mempertahankan sumber plasma nutfah komoditas-komoditas yang khas Indonesia, meningkatkan usaha-usaha pemuliaan tanaman untuk memperoleh varietas yang lebih kompetitif dari sisi kualitas maupun penyediaan komoditas pertanian untuk pasar ekspor.

Selanjutnya, guna dapat bersaing dalam perdagangan internasional juga diperlukan nilai tambah dalam setiap produk. Menurut mantan Menteri Koperasi dan Usaha Kecil Menengah era Presiden, BJ Habibie, Adi Sasoso, setidaknya ada beberapa hal yang harus dilakukan agar produk pertanian Indonesia bisa memenuhi standar internasional. Apalagi, perdagangan internasional memerlukan kesinambungan, tidak bisa hanya sekali ekspor lalu berhenti. Karena biasanya kontrak perdagangan berjangka panjang. Seperti pada perusahaan kelapa sawit, namun Ketua Dewan Rempah Nasional ini menyayangkan sawit masih diperdagangkan dalam bentuk crude palm oil (CPO) belum beranjak pada produk turunannya. Dia juga mencontohkan rotan dari Indonesia dengan mudah diekspor tanpa diolah.Akibatnya China yang menjadi salah satu tujuan ekspor saat ini sudah mempunyai stok rotan hingga 15 tahun mendatang. Bahkan produk rempah yang menjadi salah satu andalan Indonesia sejak zaman dahulu masih diekspor dalam bentuk mentah. Selama ini standardisasi masih belum menjadi kewajiban sebagai syarat dalam sebuah perdagangan.Kalau standar teknis sebenarnya sudah dilakukan dan dikembangkan badan standardisasi nasional yang didukung Kementerian Pertanian (Anonimus, 2011)

Selanjutnya, memberikan nilai tambah pada produk pertanian. Kemudian bagaimana membangun jaringan infrastruktur seperti bantuan gudang,kebijakan pembiayaan yang lebih beragam sesuai dengan jenis usaha. Secara umum terdapat beberapa syarat yang harus dipenuhi industri dan perdagangan produk pertanian dalam perdagangan internasional. Seperti sanitary (sanitasi) dan phytosanitary measures (fitosanitasi), bantuan domestik, akses pasar,dan subsidi ekspor (Pasquali, 1995).

Untuk syarat pertama biasanya standar ketat yang diterapkan negara pengimpor. Negara pengimpor diizinkan membuat standar tersendiri sepanjang tidak ada unsur diskriminasi. Selanjutnya, guna mendapatkan nilai lebih dari perdagangan internasional itu produk pertanian 
Jurnal EKOBISTEK, Vol.10, SNo. 1. Januari 2021, Hal 57-64, ISSN : 2301-5268 | E-ISST : 2527-9483 Copyright@2021 6y LPPSM VPI YPTK Padang

Indonesia harus bisa memenuhi standar yang telah ditetapkan. Agar produk bisa langsung masuk dalam pasar internasional dan tidak dipermainkan pada pedagang hanya karena tidak memenuhi standar (Anonimus, 2011).

Irawan, Bambang dan Ening Ariningsih (2020) menyatakan bahwa agar dapat memanfaatkan peluang pasar sayuran dan buah yang semakin besar baik di pasar dalam negeri maupun di pasar dunia maka diperlukan upaya peningkatan produksi dan kapasitas produksi sayuran dan buah. Secara agronomis peningkatan produksi tersebut dapat ditempuh melalui peningkatan luas panen dan/atau peningkatan produktivitas.

Tantangan utama yang dihadapi Indonesia pada agribisnis sayuran dan buah dalam memasuki era perdagangan bebas dan pasar bersama ASEAN adalah: "bagaimana Indonesia dapat membendung impor sayuran dan buah khususnya yang dapat diproduksi secara lokal dan meningkatkan ekspor tanpa dukungan kebijakan proteksi perdagangan dan kebijakan subsidi harga input dan harga output". Atas dasar tersebut maka terdapat 6 hal yang harus diperhatikan yaitu: (a) meningkatkan kualitas sayuran dan buah yang sesuai dengan preferensi konsumen di dalam negeri dan sesuai dengan standar kualitas produk yang berlaku di negara importir, (b) meningkatkan produksi sayuran dan buah dalam kuantitas yang sesuai dengan kebutuhan konsumen di dalam negeri dan negara importir, (c) meningkatkan efisiensi produksi yang dapat menekan biaya produksi per unit produk, (d) membangun sistem logistik yang efisien dan mampu mengendalikan pasokan produk secara tepat waktu, tepat kualitas dan kuantitas yang dibutuhkan pasar dengan biaya murah, (e) menciptakan iklim investasi yang kondusif bagi pengembangan agribisnis sayuran dan buah, dan (f) mengendalikan serta menjaga stabilitas nilai tukar rupiah (Irawan, Bambang dan Ening Ariningsih, 2020)

Berbagai upaya di atas hendaknya diterapkan secara bersama sama karena masing-masing aspek memiliki fungsi yang berbeda dan memiliki keterkaitan. Peningkatan kualitas diperlukan agar produk yang dihasilkan dapat diterima pasar sesuai dengan preferensi konsumen. Peningkatan produksi diperlukan agar kuantitas kebutuhan pasar dalam negeri dan kebutuhan ekspor dapat dipenuhi. Penurunan biaya produksi per unit produk diperlukan agar pada segmen pasar yang sama produk yang dipasarkan relatif murah sehingga mampu bersaing dengan produk yang dipasarkan oleh negara produsen lainnya. Pembangunan sistem logistik yang efisien diperlukan agar pasokan produk ke pasar konsumen dapat dilakukan secara tepat waktu, sesuai kualitas dan kuantitas yang dibutuhkan pasar, dan dengan biaya tata niaga relatif murah. Sedangkan menciptakan iklim investasi yang kondusif dan pengendalian nilai tukar rupiah diperlukan untuk 
Jurnal EKOBISTEK, Vol.10, No. 1. Januari 2021, Hal 57-64, ISSN : 2301-5268 | E-ISSN : 2527-9483

Copyright@20216y LPPM VPI YPTK Padang

menjamin keuntungan usaha para pelaku agribisnis (Irawan, Bambang dan Ening Ariningsih, 2020)

Berdasarkan hal di atas maka strategi untuk memanfaatkan peluang pasar produk pertanian dimulai dari pemberdayaan petani sehingga petani dapat menghasilkan produk yang baik. Selanjutnya, produk pertanian harus mempunyai standar mutu yang baik sesuai dengan yang disyaratkan dalam perdagangan internasional. Seterusnya, meningkatkan dan mengefektifkan lobi perdagangan oleh para eksportir di Indonesia sehingga dapat menjual produk pertanian pada importer di luar negeri dengan harga yang lebih tiggi. Terakhir, diperlukan nilai tambah lebih untuk meningkatkan nilai jual produk pertanian maka perlu didorong pengembangan industri pengolahan hasil pertanian.

Berdasarkan pembahasan dari analisis referensi di atas maka diharapkan kiranya agar eksportir dapat memperluas pasar produk pertanian Indonesia dalam perdagangan internasional dengan melakukan promosi (tour) ke negara-negara tujuan ekspor. Selanjutnya, supaya strategi-strategi di atas dapat diterapkan oleh stakeholder terkait.

\section{KESIMPULAN}

Dari penelitian diatas di dapatlah kesimpulan dibawah ini;

1. Peluang pasar ekspor sangat terbuka lebar bagi para petani di Indonesia, sehingga diharapkan produk komoditas yang dihasilkan para petani dalam negeri bisa bersaing dengan produk lainnya dari negara tetangga.

2. Produk-produk pertanian yang termasuk ke dalam produk perkebunan yang memiliki peluang ekspor yang cukup baik dalam perdagangan internasional diantaranya adalah teh, karet, kopi, sawit, rotan, cengkeh, kapulaga, kulit manis, pala, gambir, tebu (gula), dan coklat.

3. Produk-produk pertanian yang termasuk ke dalam produk hortikultura yang memiliki peluang ekspor adalah sayuran seperti Cabbage (sayur pangsit) dan bayam, buah-buahan seperti manggis, pepaya, pisang, dan salak, serta tanaman hias seperti Palem Jari (Raphis Excelsa).

4. Produk-produk pertanian yang termasuk kedalam peternakan yang memiliki peluang ekspor yaitu produk olahan hasil peternakan yaitu rendang diekspor ke negara-negara Amerika dan negara-negara lainnya di seluruh dunia.

5. Strategi untuk memanfaatkan peluang pasar produk pertanian dimulai dari pemberdayaan petani sehingga petani dapat menghasilkan produk yang baik. Selanjutnya, produk pertanian harus mempunyai standar mutu yang baik sesuai dengan yang disyaratkan dalam 


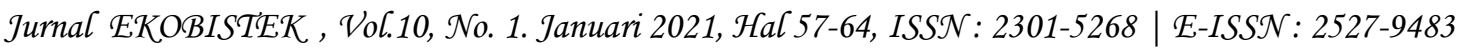
Copyright@2021 by LPPM VPI YPTK Padang

perdagangan internasional. Seterusnya, meningkatkan dan mengefektifkan lobi perdagangan oleh para eksportir di Indonesia sehingga dapat menjual produk pertanian pada importer di luar negeri dengan harga yang lebih tiggi. Terakhir, diperlukan nilai tambah lebih untuk meningkatkan nilai jual produk pertanian maka perlu didorong pengembangan industri pengolahan hasil pertanian.

\section{DAFTAR PUSTAKA}

Anonimus. 2011. Tips Pemasaran Ekspor Bagi Produk Pertanian. http://bisnisukm.com 2011. http://www.seputar-indonesia.com

2011. Mengapa Peoduk Kita Sulit Diekspor. http://inspirasitabloid. wordpress.com

Hutabarat, Budiman. 2006. Analisis Saling Pengaruh Harga Kopi Indonesia dan Dunia. Pusat Analisis Sosial dan Ekonomi dan Kebijakan Pertanian. Bogor.

Irawan, Bambang dan Ening Ariningsih. 2020. Agribisnis Sayuran dan Buah: Peluang Pasar, Dinamika Produksi dan Strategi Peningkatan Daya Saing. http://www.litbang.pertanian.go.id

Pasquali, 1995. http://www.seputar-indonesia.com

Reni Kustiari, Helena J. Purba, dan Hermanto. 2016. Analisis Daya Saing Manggis Indonesia di Pasar Dunia (Studi Kasus Sumatera Barat). Jurnal Agro Ekonomi. http://repository.pertanian.go.id.

Suprihartini, Rohayati. 2005. Daya Saing Ekspor Teh di Indonesia di Pasar Teh Dunia. Lembaga Riset Perkebunan Indonesia. Bogor. 